\title{
COMUNICADOR E TRABALHO: O PSEUDOMUNDO DA FELICIDADE NA SOCIEDADE DE CONSUMO
}

\author{
THE COMMUNICATOR AND WORK: THE PSEUDO-WORLD OF HAPPINESS IN THE \\ CONSUMER SOCIETY
}

EL COMUNICADOR Y EL TRABAJO: EL PSEUDOMUNDO DE LA FELICIDAD EN LA SOCIEDAD DE CONSUMO

Ana Maria Dantas de Maio Doutoranda, Universidade Metodista de São Pauloanamaio@uol.com.br

Marcelo da Silva Doutor, Universidade Federal do Paraná marcelosilva_rp@hotmail.com

\section{Resumo}

$\mathrm{Na}$ sociedade contemporânea, o sujeito-comunicador assume distintas identidades em diferentes momentos de seu trabalho, caracterizado pelas pressões do deadline, pelos imperativos da sociedade de consumo e pela necessidade de "convencer", intrínseca à comunicação organizacional. Por meio da ACD (Análise Crítica de Discurso) e da AD (Análise de Discurso), mergulhamos no universo da produção discursiva das organizações para tentar compreender o que leva esse sujeito-comunicador a reproduzir a ideologia dominante impressa na busca da eterna felicidade. Estudamos discursos de duas empresas, a Telefónica-Vivo e a Coca-Cola, e constatamos que esses profissionais não se apropriaram da autonomia vicejada por Morin; ao contrário, cederam à relação de dependência que os interpela em sua forma de sujeito na cotidianidade.

Palavras-chave: Comunicação organizacional. Consumo. Felicidade. 


\begin{abstract}
In contemporary society the communicator-subject takes up different identities at different times in his work, which is characterized by the pressures of the deadline, the imperatives of the consumer society and the need to "convince" that is inherent to organizational communication. By means of CDA (Critical Discourse Analysis) and DA (Discourse Analysis), we delve into the universe of organizations' discourse production, striving to understand what leads this communicator-subject to reproduce the dominant ideology engraved in the pursuit of eternal happiness. We studied the discourses of two companies, Telefónica-Vivo and Coca-Cola, and found that their professionals did not embrace Morin's envisioned autonomy, but instead gave in to the dependence relationship that grips them in everyday lif.
\end{abstract}

Keywords: Organizational communication. Consumption. Happiness.

\title{
Resumen
}

En la sociedad contemporánea, el sujeto-comunicador asume distintas identidades en diferentes momentos de su labor, caracterizado por las tensiones del deadline, por los imperativos de la sociedad de consumo y por la necesidad de "convencer", inherente a la comunicación organizacional. A través del ACD (Análisis Crítico de Discurso) y del AD (Análisis de Discurso), hemos sumergido en el universo de la producción discursiva de las organizaciones para intentar comprender lo que lleva ese sujeto-comunicador a reproducir la ideología dominante impresa en la búsqueda de la eterna felicidad. Investigamos discursos de dos empresas, la Telefónica-Vivo y la Coca-Cola, y verificamos que esos profesionales no se han apropiado de la autonomía sobre la que ha puesto Morin; al contrario, han claudicado a la relación de dependencia que les interpela en su forma de sujeto en la cotidianidad.

Palabras-clave: Comunicación organizacional. Consumo. Felicidad.

\section{INTRODUÇÃO}

Não é a primeira vez que pesquisadores em comunicação se sentem instigados a compreender melhor a mercantilização da felicidade construída em distintas formas de discurso. Diversos autores já exploraram o tema, dentro e fora do ambiente da comunicação organizacional. O que nos levou a mergulhar nessa seara foi o profundo interesse pelo trabalho e pelas ideologias que envolvem e norteiam o sujeito-comunicador ${ }^{1}$, pois sabemos que ele integra a polifonia dos discursos organizacionais e detém certo poder sobre a fala dos agentes institucionais.

\footnotetext{
${ }^{1}$ Ao utilizarmos a noção de sujeito, não nos referimos ao sujeito gramatical, nem ao sujeito empírico, mas a um lugar social, uma posição da qual o comunicador enuncia e se torna "dono" do seu dizer, é uma posição entre muitas que existem num mesmo indivíduo no processo de enunciação.
} 
O objetivo deste artigo é contribuir para o entendimento das razões que levam esses profissionais da comunicação a reproduzirem os discursos da conquista da eterna felicidade, do otimismo sem precedentes, do bem-estar inesgotável. Para tanto, buscamos em Morin as explicações sobre os graus de dependência e autonomia que interpelam o sujeito contemporâneo. Em Baudrillard, Bauman e Wolton encontramos respaldo para compreender as relações entre consumo, felicidade e comunicação. Van Dijk, um dos precursores da ACD (Análise Crítica do Discurso), e outros autores da AD (Análise de Discurso) nos auxiliam com a abordagem crítica e suas ponderações sobre os efeitos sociais, cognitivos e ideológicos de um texto.

Assim, analisamos duas manifestações empresariais: uma matéria divulgada pela assessoria de comunicação da empresa Telefónica-Vivo e uma campanha publicitária, em forma de vídeo, da Coca-Cola. Nesses dois casos, constatamos as intensas pressões mercadológicas que induzem o profissional de comunicação a reproduzir em seus discursos os padrões da busca da felicidade por meio do consumo. Esses mesmos profissionais disseminam as ideologias que interessam a suas organizações, muitas vezes de forma acrítica, pois são coagidos a agir desse modo. Poucas são as organizações que proporcionam espaços elásticos para uma atuação mais crítica

\section{A RIQUEZA DOS GÊNEROS COMUNICACIONAIS}

A $\mathrm{AD}$ e a $\mathrm{ACD}$ fundamentam teórica e metodologicamente este artigo. As técnicas para nossas análises foram aplicadas à luz das teorias cognitivas e da ideologia para a depreensão de alguns sentidos nos discursos estudados. Optamos por avaliar dois gêneros de discursos organizacionais: um jornalístico, produzido pela assessoria de imprensa da empresa Telefónica-Vivo, e outro publicitário, elaborado pela equipe de comunicação que atende à Coca-Cola.

Por meio da $\mathrm{AD}$ e da $\mathrm{ACD}$, verificamos que é possível compreender as restrições e dificuldades que impedem a atuação crítica dos sujeitos-comunicadores em sua rotina de trabalho, pois temos acesso às falas por eles produzidas e ao contexto que envolve a análise de discurso. 
Selecionamos o material intencionalmente por abordar o tema da felicidade e do otimismo ligados ao consumo, pois entendemos que as pressões mercadológicas e profissionais levam os comunicadores a construir discursos que reproduzem a ideologia capitalista dominante. A busca da matéria jornalística foi realizada em diversas salas de imprensa de sites de organizações, nas quais tivemos acesso a produtos institucionais. A campanha da Coca-Cola foi localizada pelo site de busca Google, equacionando as palavras "campanha", "lança" e "felicidade": surgiu o vídeo "Coca-Cola sharing can", ainda na versão em inglês.

Os resultados das análises são apresentados logo após a fundamentação teórica, que ilumina nosso entendimento a respeito da construção e reprodução do pseudomundo da felicidade por meio da linguagem.

\section{SOBRE A NOÇÃO DE SUJEITO NO MUNDO CONTEMPORÂNEO}

À medida que as pesquisas na contemporaneidade avançam na compreensão da relação entre cultura e comunicação, de uma saída teórica e política para os problemas na América Latina que perpassam a questão da hibridação, da mestiçagem cultural, tal intento, afirma Jacks (1995), contempla o reconhecimento do sujeito e da pertinência de uma teoria que parta das percepções deste sujeito e de sua subjetividade.

Não se trata aqui de traçar uma trajetória histórica totalizante do sujeito, senão conceber o que se quer revelar dele em meio à singularidade das culturas, às diversas formas de materialidade discursiva e ideológica, a um mundo que perpassa o planeta global, "pretensamente" unificado e ao universo do trabalho em comunicação em distintos contextos organizacionais.

Nessa busca temos a subjetividade não como espaço que se desloca somente para o ponto psicológico/individual, nem se sintetiza ao reflexo do mundo social/sistêmico, mas o que queremos é investigar o lugar social da subjetividade, definida como sendo "[...] a vida interior, as opções mais íntimas marcadas por um ethos em que a sociabilidade assume um tom caracteristicamente marcante", constituinte do sujeito (VELHO, 1991, apud SOUSA, 1995, p. 33).

Parece-nos complicado dimensionar as porções individual e social na formação da subjetividade. O fato é que à medida que novas formas de subjetivação são descobertas no meio social, surgem novos prismas de estudos: como, na prática cotidiana, as pessoas 
encontram elos para relacionar-se consigo mesmas; como se veem a si mesmas e como constroem sua identidade de sujeito na complexidade do "caldo social contemporâneo".

A própria Comunicação Social como processo, ou os veículos que ela utiliza, participa da construção da subjetividade. Daí porque, diz Sousa (1995), a relação entre subjetividade e mundo simbólico ${ }^{2}$ faz desse último uma ponte para a própria construção do imaginário.

Segundo Fígaro-Paulino (2001), o homem é individual/social porque tem na constituição de sua subjetividade, a subjetividade de um corpo social, histórico, cultural, marcado e distinto de outras sociedades, que foi apropriada de forma particular e pessoal; é um indivíduo/sujeito universal, fruto das relações sociais e da luta de classes e, ao mesmo tempo, absolutamente único e particular, apto a compreender e ser compreendido nos sentidos básicos e próprios do humano. É um indivíduo que trava consigo mesmo uma batalha, luta por ser sujeito do seu dizer, da sua existência e não apenas assujeitado pela língua e pelo sistema social, econômico, político e cultural no qual está imerso.

O sujeito assume identidades diferentes em diferentes momentos, identidades que não são unificadas ao redor de um "eu" coerente. Dentro de nós há identidades contraditórias, empurrando em diferentes direções, de tal modo que nossas identificações estão sendo continuamente deslocadas. (HALL, 2011, p. 13).

Esse sujeito insere-se numa determinada época histórica, num determinado espaço, num determinado conjunto de relações sociais e contexto cultural. Os sujeitos são plurais na medida em que atuam na cotidianidade e vão se constituindo da polifonia dos discursos que circulam na sociedade.

Sousa (1995) argumenta que, muito embora esse sujeito da comunicação na contemporaneidade não esteja configurado teoricamente, sabe-se que ocupa um espaço contraditório: o da negociação, o da busca de significações e de produções incessantes de sentido na vida cotidiana. "O receptor deixa de ser visto, mesmo empiricamente, como consumidor necessário de supérfluos culturais ou produto massificado apenas porque consome, mas resgata-se nele também um espaço de produção cultural” (SOUSA, 1995, p. 26-27).

\footnotetext{
${ }^{2}$ Se só conhecemos o real através do simbólico, só temos acesso ao simbólico através do imaginário. O simbólico em si mesmo não nos é dado... é o processo subjetivo pelo qual os homens se apoiam no real e tentam imaginariamente resolver suas contradições (SILVEIRA; DOARY apud SOUSA, 1995, p. 34).
} 
É um enunciatário mais bem percebido no universo da cultura em produção, da cultura popular, em que a própria comunicação encontra-se, surgindo da observação dessas novas situações empíricas, dando chance para o encontro do sujeito.

Destaca-se que essa mudança metodológica, donde o sujeito é inserido, que dos meios passa às mediações, à trama cultural, aos modos de ver, é resultado de uma lógica menos ligada à razão e mais sensível ao mundo social plural, à percepção da pluralidade dos atores sociais.

Tal pluralidade possibilita outras costuras explicativas na identificação do lugar da comunicação na contemporaneidade. Costuras estas que preveem levar em conta os processos políticos, econômicos, envolvendo inclusive esferas ideológico-culturais, já que essas esferas fazem morada no plano discursivo.

Conforme Thompson (1998, p. 152), muitas das formas culturais do mundo de hoje, em vários graus de extensão, são culturas híbridas em que diferentes valores, crenças e práticas se entrelaçam profundamente. Isso não implica que a globalização da comunicação através da mídia eletrônica não tenha produzido novas formas de dominação e de dependência culturais. Mas isto também não quer dizer que não possamos entender estas novas formas, suas consequências e como os sujeitos se apropriam disso.

O reinado da comunicação também tem seu revés. Se o homem moderno é livre, ele se encontra frequentemente sozinho, ou até mesmo dessocializado. Livre, mas sozinho, numa sociedade em que os laços familiares, corporativistas, socioculturais são muito menos fortes do que outrora. (WOLTON, 2006, p. 30-31).

Temos que o sujeito é dialético e dialógico, conflui na contradição própria do seu existir uno e social. Dialógico por apenas ser sujeito quando capaz de constituir-se também do outro, e dos outros que constituem sua história pessoal de vida; dialético porque se constitui nesse ir e vir uno e social. Estamos falando de um sujeito heterogêneo, com esperança de encontrar a fonte restauradora da totalidade nunca alcançada, que se constrói nas relações sociais, entendidas como espaço de imposições, confrontos, desejos, paixões, retornos, imaginação e construções (GERALDI, 1996).

Morin (2009) diz que, se pensarmos no fato de que somos seres ao mesmo tempo físicos, biológicos, sociais e culturais, psíquicos e espirituais, torna-se evidente que a complexidade é aquilo que tenta conceber a articulação, a identidade e a diferença de todos estes aspectos. $\mathrm{O}$ 
sujeito é compreendido então, como um organismo complexo capaz de pensamento. Morin (1997) define sujeito como o indivíduo considerado em duas dimensões: a autonomia e a dependência. Com efeito, o sujeito é autônomo e tem consciência de que é um indivíduo único, dotado de identidade própria. Todavia, esse indivíduo está ciente, ademais, de que depende de outros seres (da mesma ou de outra espécie) para construir a própria individualidade $^{3}$. Assim, asseveramos que fora da relação com a alteridade, não pode haver sentido:

Mesmo que os outros sejam o inferno, o homem está inelutavelmente preso ao outro naquilo que há de mais caracteristicamente humano, a linguagem. A alteridade é uma dimensão constitutiva do sentido. Não há identidade discursiva sem a presença do outro. (BARROS; FIORIN, 2003, p. 36).

Para Morin, citado por Galembeck e Veasey (2008), ser sujeito não é ser consciente nem ter afetividade, mas tão somente colocar-se no centro de seu próprio mundo. É ocupar-se de si: "Computo ergo sum". Esclarece dizendo que todo mundo pode dizer "eu", contudo, cada um de nós, só pode ser "eu" por si próprio (autonomia). Ninguém pode dizer "eu" pelo outro. Ser sujeito é colocar-se no centro do seu próprio mundo; é ao mesmo tempo, ser autônomo e dependente. Dependente do meio, que é anterior e autônomo, enquanto ocupa-se de si. Ser consciente é ter a capacidade de sair de si, de transcender a centralidade da subjetividade, percebendo, ao mesmo tempo, que nosso modo de ser é ser o centro de nosso mundo.

O sujeito se constitui em todas as formas de discurso. Sabemos que o pensamento humano é expresso na sua gênese por meio de imagens. A tesoura do sujeito comunicador em sua rotina de trabalho marca uma forma peculiar de ver a realidade, de representá-la por meio de valores emergentes: felicidade, bem-estar, amor, paz, otimismo e confiança. A representação da felicidade nas ações de comunicação é objeto de reflexão deste artigo, considerando que agora já compreendemos que o sujeito comunicador age a interage no mundo do trabalho com dependência - e suas eventuais pressões - e certo grau de autonomia.

\footnotetext{
${ }^{3}$ A noção de sujeito, em Morin, fundamenta-se em dois princípios, inseparáveis e associados, o princípio da exclusão e o da inclusão. O princípio da exclusão baseia-se na instituição do "eu" como elemento único e central: é a consciência da individualidade e da subjetividade. Mas a exclusão pressupõe a inclusão, pois o "eu" só existe em função do outro com o qual mantemos relações ("você") e de outros seres com os quais nos integramos ("nós"). Em outros termos, pode-se admitir que o ser humano - dotado de linguagem e cultura institui-se a si mesmo como um ser único [o "eu", seguramente, não tem plural, mas, do mesmo modo, ele não pode deixar de levar em consideração o interlocutor ("você") e o grupo no qual ele se insere ("nós")]. O "eu" isolado não existe, porque o sujeito e o outro se complementam e é nessa complementaridade que o ser humano pode exercitar a sua liberdade, como tal entendida a capacidade de escolha. (GALEMBECK; VEASEY, 2008).
} 


\section{a. Discurso, ideologia e felicidade}

O que leva, então, esse sujeito a persistir na reprodução do pseudomundo da felicidade através do estímulo ao consumo? Para Bauman (2008, p. 60), “o valor mais característico da sociedade de consumidores, na verdade seu valor supremo, em relação ao qual todos os outros são instados a justificar seu mérito, é uma vida feliz". É inimaginável, na sociedade ocidental contemporânea, que uma organização busque associar sua marca ou imagem a aspectos cotidianos não ligados à felicidade, ao otimismo e ao bem-estar.

Podemos inferir, a partir desta constatação, que o comunicador que atua em organizações - seja nas áreas de relações públicas, publicidade e propaganda ou jornalismo - vai buscar sempre um link da empresa com algumas proposições positivas de existência. Até porque, "na sociedade de consumidores a infelicidade é crime passível de punição, ou no mínimo um desvio pecaminoso que desqualifica seu portador como membro autêntico da sociedade" (BAUMAN, 2008, p. 61).

Outro autor que se debruça sobre a questão da felicidade e do bem-estar nos discursos é Baudrillard. Para ele, "a felicidade constitui a referência absoluta da sociedade de consumo" (BAUDRILLARD, 2010, p. 47) e, em função disso, torna-se um mito perseguido pelos indivíduos que convivem nessa sociedade. O comunicador é, por essência, um potencial fabricador de mitos, já que, no lugar de enunciador, tem acesso aos instrumentos de comunicação dirigidos e massivos, ainda relevantes na atualidade para o processo de disseminação de símbolos.

\footnotetext{
A força ideológica da noção de felicidade não deriva da inclinação natural de cada indivíduo para a realizar por si mesmo. Advém-lhe, socio-historicamente, do facto de que o mito da felicidade é aquele que recolhe e encarna, nas sociedades modernas, o mito da Igualdade (BAUDRILLARD, 2010, p. 47, grifo do autor).
}

Estaria, portanto, o sujeito-comunicador imbuído das melhores intenções ao perseguir a fabricação do discurso a respeito do pseudomundo da felicidade? Rejeitar ou seguir na contramão desta tendência parece uma hipótese tão despropositada que nem deveria ser cogitada. Todavia, o comunicador raramente reflete sobre as consequências que seu trabalho provoca nesta sociedade. Um dos pensadores que se preocupa com os rumos que a 
comunicação segue e com a retomada de seus valores é Wolton (2004, p. 267), segundo o qual

\begin{abstract}
A questão é saber como salvar os valores de liberdade e emancipação que sustentaram a história da luta pela informação e pela comunicação. A solução consistiria em fazer o contrário do que geralmente se empreende. Diminuir a velocidade em vez de acelerar, organizar e racionalizar em vez de aumentar os volumes de informação, reintroduzir intermediários em vez de suprimi-los, regulamentar em vez de desregulamentar.
\end{abstract}

A proposta de Wolton é um caminho na direção de uma comunicação mais humanizada, menos mecânica e pragmática. Resta saber se o comunicador tem a suficiente autonomia para controlar o conteúdo, os efeitos de sentidos que seus discursos provocam e o processo da comunicação na organização em que atua, para que possa agir com responsabilidade, especialmente em relação às expectativas e frustrações que cria no receptor.

Para Van Dijk (2005, p. 24), "aqueles que têm maior controlo sobre mais - e mais influente - discurso (e mais características do discurso) são por definição também mais poderosos". Poder, autonomia e imaginário são instâncias inter-relacionadas, na medida em que a própria noção de poder é posta em xeque por Baudrillard (1991, p. 34): “também o poder desde há muito que não produz senão os signos da sua semelhança". Para ele, o poder deixou de ser efetivo/real para se tornar simulacro da realidade, esvaziando o conceito e a autoridade de quem se pretendia poderoso.

Além disso, no que tange ao poder, à autonomia e ao imaginário, concordamos que "as relações de poder são discursivas" (Van DIJK, 2005, p. 20), ou seja, integram o mundo simbólico construído por meio do imaginário, dos simulacros e das simulações.

O mundo dos signos - expresso pelos discursos - revela ainda os confrontos ideológicos que envolvem as relações de grupos - e, consequentemente, de poder. "As ideologias são definidas como sistemas básicos de cognições sociais fundamentais e como princípios organizadores das atitudes e das representações sociais comuns a membros de grupos particulares" (Van DIJK, 2005, p. 135).

A opção por enunciados que fidelizam o pensamento do receptor à ideia da felicidade constante se dá, portanto, por pressões mercadológicas, mas também por decisão autônoma do comunicador, baseado nos modelos mentais, como veremos adiante. É possível que este profissional sequer questione os porquês que o levam a produzir e reproduzir tais discursos, de tão automatizadas que são suas elaborações discursivas. 
Neste caso, cabe ao comunicador uma postura mais crítica em relação aos impactos sociais e cognitivos que seus enunciados podem provocar. Sem essa reflexão, os mesmos modelos mentais continuarão reproduzidos e multiplicados na sociedade de consumo, ratificando a busca pelos ideais de felicidade, do amor e do compartilhamento a qualquer custo, secundarizando as agruras e depressões vivenciadas pelos sujeitos que não se sentem permanentemente felizes. Lembramos que os discursos ganham materialidade de exclusão: quem não consome não pode ter acesso à felicidade roteirizada no discurso organizacional, seja publicitário ou jornalístico.

\title{
4 A GERAÇÃO DO MILÊNIO E A LATINHA DIVIDIDA 4
}

A Análise Crítica de Discurso, preconizada por Van Dijk, dá conta de avaliar os enunciados, seus contextos e as relações que se estabelecem entre as estruturas cognitivas dos participantes, os discursos e as ideologias. Essa modalidade de investigação da linguagem se preocupa com relevantes problemas sociais e consideramos que, ao escolhê-la para fundamentar a análise da matéria jornalística, podemos colocar o consumo excessivo de bens materiais (incluindo as tecnologias) e simbólicos em um patamar de descontrole do equilíbrio social.

\begin{abstract}
A Análise Crítica do Discurso (ACD) é um tipo de investigação de análise do discurso que estuda, em primeiro lugar, o modo como o abuso do poder social, a dominância e a desigualdade são postos em prática, e igualmente o modo como são reproduzidos e o modo como se lhes resiste, pelo texto e pela fala, no contexto social e político. (Van DIJK, 2005, p. 19).
\end{abstract}

Essa visão crítica será aplicada na análise da matéria "Pesquisa da Telefónica revela que geração do milênio brasileira está confiante no futuro do país, preocupada com mudanças climáticas, desigualdade social e educação", localizada entre os press-releases divulgados pela empresa de telefonia Telefónica-Vivo, produto da comunicação organizacional da empresa.

Assim, pensamos que o sujeito-enunciador e sujeito-enunciatário inscrevem-se em lugares determinados na estrutura de uma formação social que, atreladas às condições de produção de discursos, representam "uma série de formações imaginárias que designam o lugar que A e B

\footnotetext{
${ }^{4}$ A campanha da Coca-Cola traz o lançamento da latinha de refrigerante que se divide em duas miniembalagens, para que o consumidor compartilhe metade da bebida com outra pessoa (Cf. referência Coca-Cola).
} 
(sujeito-enunciador e sujeito-enunciatário) se atribuem cada um a si e ao Outro, a imagem que eles se fazem de seu próprio lugar e do lugar do Outro" (PÊCHEUX; FUCKS, 1997, p. 82).

Conforme veremos adiante, a matéria institucional encaixa-se no perfil de enunciador totalmente dependente da lógica e das pressões do mercado. Nem mesmo o autor do texto é nominalmente identificado. A relação entre consumo de tecnologia e otimismo faz-se presente ao imprimirmos um olhar para as vicissitudes do discurso que se materializa num funcionamento que privilegia uma ideologia.

No caso da campanha da Coca-Cola, observamos que o discurso constrói-se sob o arquétipo da felicidade, vinculado à ideia do compartilhamento e de imagens que tratam da cotidianidade do indivíduo na interação com o outro; característica própria da sociedade atual, esses elementos apresentados no discurso mercadológico da Coca-Cola interpelam o consumidor em um quadro de trocas cotidianizadas em cenas universais.

\section{a. Tecnologia e otimismo: o discurso da Telefónica}

Quando Van Dijk se dispõe a realizar análises críticas de discurso, ele inclui nos estudos a avaliação dos contextos global e local, das ideologias dos endogrupos (a polifonia do grupo que fala) e dos exogrupos (os outros, geralmente desqualificados pelos primeiros), de várias categorias que envolvem a construção do texto (lexicais, semânticas, sintáticas, retóricas, entre outras), dos tópicos e, baseado em teorias cognitivas, dos modelos mentais dos enunciadores.

Os modelos são representações mentais de acontecimentos, acções ou situações vividas pelas pessoas, ou sobre os quais elas lêem. O conjunto destes modelos representa as crenças (conhecimento e opiniões) que as pessoas têm sobre as suas vidas quotidianas e define aquilo a que usualmente chamamos de 'experiências' pessoais. (Van DIJK, 2005, p. 119).

São esses modelos mentais que fundamentam, orientam e influenciam os pensamentos do enunciador e do enunciatário. Envolvidos pela ideologia dominante, os autores do discurso polifônico e os receptores - igualmente participantes do processo comunicativo - podem associar, cognitivamente, consumo à felicidade, desde que essa seja a tônica da enunciação.

No caso da empresa de telefonia, a matéria sobre a geração do milênio brasileira apresenta os resultados de uma pesquisa realizada pela Telefónica e pelo Financial Times a respeito da 
relação entre a chamada geração $\mathrm{Y}^{5}$ - jovens com idades entre 18 e 30 anos - e a tecnologia. O endogrupo, composto pelas empresas promotoras do levantamento, pelo presidente da Telefónica (representante do gênero masculino), pelo mercado, pela tecnologia, pelos comunicadores que escreveram o enunciado, pela geração do milênio e seus líderes, esforçase para estabelecer uma relação concreta entre essa geração que exalta a tecnologia com um perfil de jovens que se preocupa com questões sociais e ambientais.

O tópico do enunciado demonstra essa tendência: "Pesquisa da Telefónica revela que geração do milênio brasileira está confiante no futuro do país, preocupada com mudanças climáticas, desigualdade social e educação". E mais: "Brasil tem uma das maiores concentrações globais de líderes da geração do milênio otimistas e entusiastas da tecnologia". Segundo Van Dijk (2005, p. 182), “em termos intuitivos, os tópicos exprimem aquela que é considerada a informação 'mais importante' de um discurso".

Avaliamos como "esforço" a tentativa da organização de associar os jovens a esse perfil porque os dados da pesquisa apresentados no texto são frágeis, induzindo a uma aparente contradição. A preocupação com educação e desigualdade social que consta no item topicalizado foi citada por $24 \%$ dos entrevistados, sugerindo que a grande maioria, $76 \%$ deles, não mencionou tais inquietações (dado intencionalmente não dito). A preocupação com a saúde foi apontada por $17 \%$ dos jovens e com a pobreza, por $11 \%$. O pseudoengajamento que a empresa propõe se dilui na leitura crítica dos sentidos que ficam apensos no discurso.

A presença do nome da organização como sujeito de fala no título ("Pesquisa da Telefónica revela") cria um elo com os temas sociais e ambientais enumerados, como se a companhia estivesse, igualmente, preocupada com tais assuntos, postura que se apresenta como politico-institucionalmente correta no quadro significativo de um discurso que se quer e se mostra outorgado pela sociedade.

Em relação a "uma das maiores concentrações globais de líderes", identificada no Brasil, os números indicam que chegam a $18 \%$, embora a construção textual com uso de comparativo sugira um volume mais expressivo. A estratégia de se trabalhar com a inversão de dados pode ser uma forma de manipular a mensagem, como outras que localizamos no texto. A escolha lexical do verbo "acreditar" é um exemplo. Ele aparece na matéria 17 vezes, sempre acompanhado do sujeito "os jovens" ou "os entrevistados". O discurso da organização quer

\footnotetext{
${ }^{5}$ No texto, a assessoria esclarece que a geração do milênio também é conhecida como geração Y. ANIMUS
} 
fazer crer que essa geração tem como verdade as proposições que seguem o verbo, quando o "acreditar" é uma ação totalmente subjetiva e inapropriável.

Outra escolha lexical marcante e que estabelece limites do endogrupo é o verbo "trazer", na seguinte construção: “os líderes da geração do milênio são os entrevistados que acreditam estar na vanguarda de tecnologia, $[. .$.$] e ter a oportunidade de tornarem-se empreendedores ou$ desenvolver e trazer uma ideia para o mercado". Este fragmento do discurso denota posicionamentos: o endogrupo representa o mercado e busca aproximá-lo da geração Y ou, ao menos, de suas lideranças. Ao mesmo tempo, o uso da expressão "da geração do milênio" lhe outorga toda e qualquer capacidade de transformar o mundo e as relações por meio da tecnologia e do empreendedorismo, escamoteando questões típicas da contemporaneidade e de tal geração, marcada pela superficialidade, dificuldade de relacionamento, individualismo, identidade lábil e exageradamente pragmática e tecnicista.

Van Dijk (2005) acrescenta que nas construções discursivas, o endogrupo procura com frequência realçar suas qualidades e as fraquezas alheias, estabelecendo polarizações acentuadas, sempre que possível. É o que encontramos em citações como "nosso compromisso com a educação e as atividades sustentáveis”, “a Telefónica [...] está envolvida em várias atividades importantes que causam real impacto na vida das pessoas e na sociedade", ou ainda, "a Telefónica é uma das maiores empresas de telecomunicação do mundo", apenas para selecionar algumas passagens. Um exemplo da tentativa de desqualificar o exogrupo é quando a organização anuncia servir "mais do que o total dos municípios atendidos pelas demais operadoras".

O exogrupo seria composto pela concorrência e pelas mulheres. $\mathrm{O}$ texto apresenta dados da pesquisa que sustentam uma lacuna de gênero em relação ao uso da tecnologia, ficando o público feminino em situação inferior, sem destaque no discurso apológico à tecnologia. Um exemplo: "os homens brasileiros da geração do milênio têm duas vezes mais probabilidade de tornarem-se líderes da geração do milênio do que as mulheres desta mesma geração (22\% comparado a 13\%)". A ideologia sexista com dominância masculina se faz presente e evidencia uma posição que constrói a imagem do sujeito-enunciador investida de sentidos que corroboram outros discursos que colocam a mulher em lugares desprivilegiados ou na posição de incapacidade.

Van Dijk (2005), ademais, coloca que o uso da voz passiva é uma possibilidade de esconder o sujeito da ação ou manter a dúvida sobre o agente. No enunciado, a voz passiva 
está ausente porque persistem a vontade e a necessidade de exibir o sujeito da fala. Os autores optam por verbos na voz ativa, no tempo presente do modo indicativo: afirma, acredita, concorda, entre outros, buscando a ideia de atualidade e assertividade.

O contexto global que envolve essa produção é representado pelo mercado mundial de alto desenvolvimento tecnológico e poucas ações efetivas contra a desigualdade social e a pobreza e a favor de uma educação de qualidade.

$\mathrm{O}$ aumento da desigualdade raras vezes é considerado sinal de alguma coisa além de um problema financeiro; nos casos relativamente raros, em que há um debate sobre os perigos que essa desigualdade representa para a sociedade como um todo, em geral ele se dá em termos de ameaças à "lei e ordem"; quase nunca dos riscos para os ingredientes fundamentais do bem estar geral da sociedade, como, por exemplo, a saúde física e mental da população, a qualidade de sua vida quotidiana, o sentido de seu engajamento político e a força dos vínculos que a integram à sociedade. (BAUMAN, 2013, p. 9).

Localmente, o discurso foi construído a partir de uma conferência realizada em São Paulo, no dia 6 de junho de 2013, intitulada "Millennials Summit: The Interactive Generation". Aqui também notamos o esforço das organizações em relacionar a geração Y ao perfil interativo, embora saibamos que tecnologia não garante, por si só, interatividade.

O enunciado faz alusão direta à felicidade, ao divulgar outro item da pesquisa: " $70 \%$ da geração do milênio [essa, que é fã e consome tecnologia] brasileira escolheu que ser feliz é mais importante do que ser rico, bem sucedido ou famoso". Mais uma vez, esse sentimento é alçado à cúpula dos ideais humanos por meio da fala do outro, que serve como argumento para legitimar a ordem desse discurso da felicidade acima de tudo, uma contradição em uma sociedade que prima pelo parecer-ser, calcada na fruição do poder e na parca ética nas relações cotidianas das organizações.

Por fim, o discurso da Telefónica confirma a ideologia consumista e tecnológica, consoante com o capitalismo, atestando que, quanto mais conectado, mais facilidades o jovem terá. Na enunciação, a tecnologia apresenta-se indissociável do sucesso, bem-estar, liderança, engajamento, otimismo, segurança e outras proposições positivas. O modelo mental do "quanto mais tecnologia, melhor" é reforçado no e pelo endogrupo, numa tentativa de influenciar a persuadir o receptor. Qualquer posicionamento crítico do sujeito comunicador está ausente, compondo o não dito desta ação discursiva, que apologiza a tecnologia e a põe como uma panaceia para as "grandes" questões da sociabilidade, olvidando-se de que todo 
aparato tecnológico e as mudanças que redundam dele não impedem o fracasso, a solidão e a incomunicação, pois ser livre e tecnológico não garante, necessariamente, o encontro de si e da alteridade.

\section{b. Coca-Cola e o encantado discurso da felicidade}

A Coca-Cola é uma das empresas que mais investem em publicidade no mundo e uma das poucas que a realiza com primazia. Há 127 anos, a comunicação da empresa tem evoluído e se valido de "novas" formas de construir seu discurso publicitário, ancorando-o em algo caracteristicamente humano: a cotidianidade. Nesse contexto, compreendemos que o discurso publicitário da Coca-Cola está intrinsecamente ligado a um produto visto como símbolo do capitalismo e do imperialismo da cultura estadunidense, como também de um paradigma da globalização e do consumo, inscrevendo-se em determinada ordem de discurso, "[...] na totalidade de práticas discursivas dentro de uma instituição ou sociedade e o relacionamento entre elas” (FAIRCLOUGH, 1989 apud RAMALHO; RESENDE, 2013, p. 19).

A cena erigida no discurso que analisamos ocorreu em Singapura - tal desenho da lata ainda não está disponível em nossos mercados - e carrega consigo elementos fundamentais: pessoas, interação, paisagem, urbanização, objetos e Coca-Cola, que é responsável por atribuir sentido aos actantes em movimento na publicidade. Nessa ambiência, a Coca-Cola, que é global, também quer ser local. É um produto internacional e de múltiplas nações, porém, quer parecer nativa nos locais em que se mostra presente, alimentando-se de "ingredientes" que constituem o homem como ser genérico na cotidianidade, haja vista que

\footnotetext{
Na vida cotidiana, a esmagadora maioria da humanidade jamais deixa de ser, ainda que nem sempre na mesma proporção, nem tampouco com a mesma extensão, muda unidade vital de particularidade e genericidade [...] $\mathrm{O}$ fato de se nascer já lançado na cotidianidade continua significando que os homens assumem como dadas as funções da vida cotidiana e as exercem paralelamente. (HELLER, 2000, p. 38).
}

Nesse sentido, o discurso analisado promove a ideia de partilha e compartilhamento no seio da cotidianidade, vindo ao encontro do espectro de uma sociedade que pode ser construída sob a égide dos relacionamentos, não mais e apenas no individualismo exagerado como propõe Bauman - propriedade inerente à sociedade coeva; a narrativa mercadológica da Coca-Cola faz funcionar seu discurso permeado pela ideologia do consumo, que é o 
realizador de atividades humanas universais: pessoas ávidas pela felicidade em uma sociedade infeliz, depressiva e individual, rindo, passeando, se divertindo em restaurantes, ruas, jardins, seja com amigos, família, namorados, conhecidos etc.

A alegria que investe o discurso e se materializa nas ações dos sujeitos da publicidade evidencia, não exatamente o produto, mas a concretização de um sonho possível por meio do consumo: mesmo diante de um sujeito clivado, de identidade instável, frente à avassaladora realidade que solapa os sonhos e o ideário da vida em harmonia - tão difundidos pelas religiões e outras filosofias de vida - Coca-Cola possibilita uma vida distante da "dureza" e desesperança: "Nós podemos e merecemos ser felizes, desde que partilhemos, dividamos e contribuamos com uma sociedade que prime pelos relacionamentos que podem ser construídos via consumo do refrigerante", o qual promove genuína felicidade, estimula a solidariedade e o viver dialógico e comunitário.

O discurso da Coca-Cola faz circular uma série de posições que lhe outorga à marca a capacidade única de engendrar a felicidade; todavia, essa apenas pode ser desfrutada no consumo da bebida e inexiste fora dele. No afã de informar, o discurso da Coca-Cola faz parecer que não apresenta uma "identidade definida", o que possibilita a identificação de todos, de diferentes lugares, etnias, raças, idades e tempos.

Entretanto, os valores de onipotência e onipresença que se assemelham a categorias divinas, caracterizam sua identidade. Seu discurso, por ser constituído "ao sabor da hora", veicula valores positivos à marca e debela/oculta ${ }^{6}$ textos que a contradizem. Isto faz da CocaCola um instrumento para a produção da felicidade, calcada em imagens arquetípicas de felicidade, refletindo a expressão de emoções, de valores axiológicos e de ideologias, pois, para Bakhtin (1999, p. 41), "o signo reflete e refrata a realidade em transformação".

As organizações, ao prestarem conta de suas práticas, do modus operandi de seu cotidiano e de suas políticas de comunicação, não têm levado em conta a resistência da alteridade frente a suas estratégias sedutoras de incentivo ao consumo, que estão no campo da informação e muito pouco - ou nada - na perspectiva da comunicação, a qual Wolton (2011) acredita ser urgente em uma sociedade cada vez mais conectada: a comunicação é cada vez menos

\footnotetext{
${ }^{6}$ Como ocorreu recentemente no Brasil por conta da denúncia de um consumidor sobre o suposto encontro de um rato dentro de uma garrafa de Coca-Cola; em seu posicionamento, a empresa deixa entrever no discurso certo teor de arrogância ao afirmar que seus processos produtivos são realizados com tamanha excelência e um rigoroso processo de qualidade e que cada detalhe é analisado com muito cuidado e primazia, deixando as portas abertas para que os consumidores visitem suas fábricas.
} 
transmissão, pouco compartilhamento, essencialmente negociação e convivência com as diferenças e o contraditório.

Se o discurso compreende a produção de sentido entre interlocutores, entendemos que a ideia de um sujeito passivo e entregue aos mandos e desmandos da comunicação mercadológica e das estratégias comunicativas das organizações, cada vez mais rumamos a uma concepção de consumidor ativo, que se informa e é capaz de ressemantizar as mensagens que são produzidas pelas organizações de diferentes campos de atuação.

Isto posto, as organizações têm investido maciçamente em publicidade, em marketing, promoções e adaptam-se às novas demandas da sociedade; com quase metade da população acima do peso $^{7}$, investir em narrativas roteirizadoras da felicidade e do compartilhamento urge como uma tendência, porém, carrega no seu bojo graves antinomias, principalmente no que tange ao discurso que apregoam. Convém ressaltar que na cotidianidade os sujeitos ressignificam determinadas posições corporativas e o eco que as múltiplas "vozes consumidoras" produzem em diferentes suportes midiático-comunicativos.

Baudrillard (1981) afirma que essa força de manipulação oriunda das campanhas publicitárias e propagandísticas não ocorre de modo direto, pois as necessidades não são produzidas "uma a uma" em relação aos respectivos objetos. Não se pode dizer que a publicidade, por exemplo, seja, sozinha, capaz de condicionar um indivíduo ao consumo de um objeto específico, até porque, no caso da Coca-Cola, o consumo é apenas mais um elemento da narrativa, que se ancora no que redunda do produto: felicidade, alegria, paz, diversão, partilha, alteridade e identidade.

A defesa do autor reside na existência de um sistema de necessidades, uma força consumptiva de natureza globalizante que envolve perspectivas psicológicas, sociais, culturais e estruturais mais abrangentes; cabe destacar, na coxia de Fígaro-Paulino (2001), que o sujeito-publicitário não pode ser encarado como um eu autônomo e autômato, livre no sentido de estar desligado, desprendido do conjunto que é a sociedade.

O sujeito-comunicador não é uma fonte absoluta de significação, capaz de criar e tirar de si mesmo todos os sentidos, pois também é produto da sociedade, das condições, das contradições e pulsões sociais, fato que corrobora nosso pensamento. Notamos que certas produções de comunicação são como são em virtude dos imperativos da sociedade capitalista de consumo, que atua em estruturas inconscientes, levando a publicidade mais à esfera do

\footnotetext{
${ }^{7}$ Consideramos que a ingestão de refrigerantes pode contribuir para esse quadro. 
espírito - característica do chamado Marketing 3.0 - que de sua essência, que é o consumo: a roteirização da felicidade que ignora os paradoxos de uma sociedade que viceja cada vez mais pelo "bem", mas o confunde com o desejo de consumir mais e mais.

\section{CONSIDERAÇÕES}

Os discursos avaliados na matéria institucional e na campanha da Coca-Cola refletem a intensa pressão mercadológica exercida sobre a atuação dos sujeitos-comunicadores. Por mais que eles tentem atuar como profissionais críticos - e recebam essa formação nas instituições de ensino -, acabam envolvidos pela lógica e pela dinâmica do mercado e entram na rodaviva da produção do discurso que prega a eterna felicidade e o otimismo infinito. Por vezes, a criação dos enunciados perpassa coações tão sutis que o profissional sequer percebe o círculo vicioso estabelecido pelo padrão discursivo.

Quando consciente das consequências que a oferta da felicidade inatingível pode causar, por vezes este comunicador tem sua autonomia limitada para amenizar o efeito de certos enunciados. Sabemos, no entanto, que é possível encontrar brechas e circunstâncias que permitam uma atuação crítica do comunicador, explorando a autonomia citada por Morin.

A felicidade e o bem-estar são materializados pelos comunicadores como mercadorias que ganham dimensões próprias e podem ser abertas, divididas, compartilhadas, como se fossem um pedaço de bolo. Seu oposto, a tristeza e o desconforto, fazem parte do não dito nos discursos organizacionais aqui analisados, são obliterados, apagados, relegados à inexistência. Aliás, é improvável localizar enunciados que façam apologia à tristeza, pois esta não interessa à ideologia capitalista e consumista dominante.

No caso da matéria da Telefónica, notamos a forma e a força com que a tecnoideologia é abarcada pelo discurso empresarial. Por mais que o comunicador tente destacar a ideia de que a geração do milênio no Brasil anda preocupada com questões relevantes, as escolhas lexicais, semânticas, retóricas, estilísticas, tópicas e sintáticas revelam o quanto o consumo da tecnologia é importante para manter essa geração feliz e otimista, ideologia que interessa sobremaneira ao mercado e disfarça os sinais da contradição derivados dos avanços tecnológicos.

Interessante também é observar, na reportagem, a contraposição de interesses entre endogrupos e exogrupos, conforme elucida Van Dijk (2005). As qualidades dos endogrupos são destacadas (e seus defeitos omitidos) e as fraquezas dos exogrupos são expostas (e suas 
fortalezas, secundarizadas ou escondidas). Destaquemos também a diversidades de vozes que se materializam no discurso do sujeito-jornalista, que traz à arena diferentes posições polifonia - que dialogam, produzem sentido e constroem um percurso de intencionalidade e de possibilidade de apreensão.

Em relação à análise da campanha do refrigerante, consideramos que a narratividade publicitária da felicidade na peça da Coca-Cola nos leva a uma reflexão acerca da cotidianidade que alimenta o trabalho da comunicação mercadológica, já que constrói o homem naquilo que lhe é mais comum: o cotidiano e os relacionamentos. Destarte, compreender essa produção discursiva não envolve somente "o processamento e a interpretação de informações exteriores, mas também a ativação e uso de informações internas e cognitivas" (Van DIJK, 1999, p. 15).

Entre otimismo, felicidade, comunhão e sorrisos, mais cedo ou mais tarde, o que foi ouvido e compreendido de forma ativa, conforme Bakhtin (1997), encontrará eco em diferentes discursos ou no comportamento ulterior do ouvinte. Este eco estará igualmente na interação polifônica de diferentes produções, de vozes que muitas vezes não falam uma "verdade", mas servem para enganar, ludibriar, escamotear e seduzir, a partir de um sujeito que acolhe as múltiplas vacilações da significação, já que possui identidades que não são unificadas ao redor de um "eu" coerente - como afirma Hall - senão de identidades contraditórias, empurradas em diferentes direções, de maneira que nossas identificações permaneçam continuamente deslocadas.

\section{REFERÊNCIAS}

BAKHTIN, Mikhail. Estética da criação verbal. São Paulo: Martins Fontes, 1997.

Marxismo e filosofia da linguagem: problemas fundamentais do método

sociológico na ciência da linguagem. Tradução de Michel Lahud e Yara Frateschi Vieira. 9. ed. São Paulo: Hucitec, 1999.

BARROS, Diana Luz Pessoa; FIORIN, José Luiz (Orgs.). Dialogismo, polifonia, intertextualidade: em torno de Bakhtin. São Paulo: Edusp, 2003.

BAUDRILLARD, Jean. 1981. A sociedade de consumo. São Paulo: Martins Fontes, 1981.

Simulacros e simulação. São Paulo: Relógio d’Água, 1991.

A lógica social do consumo. In: A sociedade de consumo. Lisboa: Edições 70, 2010. p. 47-99. 
BAUMAN, Zygmunt. Vida para consumo: a transformação das pessoas em mercadoria. Rio de Janeiro: Zahar, 2008.

Danos colaterais: desigualdades sociais numa era global. Rio de Janeiro: Zahar, 2013.

COCA-COLA. Coca-Cola sharing can. Singapura, 2013. Disponível em:

http://comunicadores.info/2013/08/01/lata-da-coca-cola-que-se-divide-para-compartilharfelicidade/. Acesso em: 10 set. 2013.

FÍGARO-PAULINO, Roseli. Comunicação e trabalho: estudo de recepção: o mundo do trabalho como mediação da comunicação. São Paulo: Anita Garibaldi, 2001.

GALEMBECK, Paulo de Tarso; VEASEY, Camila Bambozzi. O "eu" e o "outro" em diálogos simétricos - projetos Nurc/SP e Nurc/RJ - Parte I e Parte II. Revista Philologus, ano 8, n. 23. Disponível em: <http://www.filologia.org.br/revista/artigo/7(23)08.htm>. Acesso: 25 jun. 2008.

GERALDI, João Vanderley. Linguagem e ensino: exercícios de militância e divulgação. Campinas: ALB/Mercado de Letras, 1996.

HALL, Stuart. A identidade cultural na pós-modernidade. Rio de Janeiro: DP\&A Editora, 2011.

HELLER, Agnes. O cotidiano e a história. 8. ed. São Paulo: Paz e Terra, 2000.

JACKS, Nilda. Pesquisa de recepção e cultura regional. In: SOUSA, Mauro Wilton (Org.). Sujeito, o lado oculto do receptor. São Paulo: Brasiliense, 1995.

MORIN, Edgar. Cultura de massas no século XX: espírito do tempo, neurose. Rio de Janeiro: Forense Universitária, 1997.

A cabeça bem-feita: repensar a reforma, reformar o pensamento. Tradução de Eloá Jacobina. Rio de Janeiro: Bertrand Brasil, 2009.

SOUSA, Mauro Wilton (Org.). Sujeito, o lado oculto do receptor. São Paulo: Brasiliense, 1995.

PECHEUX, Michel; FUCKS, Catharine. Por uma análise automática do discurso: introdução à obra de Michel Pêcheux. (Orgs.). Campinas: Ed. Unicamp, 1997.

RAMALHO, Viviane de Melo; RESENDE, Viviane. Análise de Discurso crítica. São Paulo: Contexto, 2013.

TELEFÓNICA. Pesquisa da Telefónica revela que geração do milênio brasileira está confiante no futuro do país, preocupada com mudanças climáticas, desigualdade social e educação, 6 jun. 2013. São Paulo, 2013. 4. p. Disponível em: 
http://saladeprensa.telefonica.com/documentos/nprensa/0606_Millenialls_-_vfinal.pdf. Acesso em: 24 set. 2013.

THOMPSON, John B. A mídia e a modernidade: uma teoria social da mídia. Petrópolis, RJ: Vozes, 1998.

Van DIJK, Teun A. Cognição, discurso e interação. São Paulo: Contexto, 1999.

Discurso, notícia e ideologia: estudos na análise crítica do discurso. Famalicão:

Campo das Letras, 2005.

WOLTON, Dominique. Pensar a comunicação. Brasília: Editora Universidade de Brasília, 2004.

É preciso salvar a comunicação. São Paulo: Paulus, 2006.

Informar não é comunicar. Porto Alegre: Sulina, 2011.

Original recebido em: 29/09/2013

Aceito para publicação em: Novembro de 2013

Ana Maria Dantas de Maio

Tem graduação em Comunicação Social pela Universidade Estadual de Londrina (1990), mestrado em Comunicação pela Universidade Estadual Paulista Júlio de Mesquita Filho (2005) e iniciou em 2012 o doutorado em Comunicação Social pela Universidade Metodista de São Paulo.

Marcelo da Silva

Professor do curso de Relações Públicas da Universidade Sagrado Coração de Bauru-SP Doutorando em Comunicação Social pela Universidade Metodista de São Paulo. 